\title{
Chapter 7 \\ "Racial Attitudes and Race-Neutral Social Policies: \\ White Opposition to Welfare and the Politics of $\mathbf{R}$ \\ acial Inequality"
}

\author{
Martin Gilens \\ Department of Political Science
}

UCLA

In almost every aspect of social and economic well-being, black Americans remain worse off than whites. African Americans' median income today is $74 \%$ that of whites, a feeble improvement of only five percentage points in the past 25 years. Racial differences in high school completion rates and achievement scores on standardized tests have narrowed dramatically in the past two decades. But the racial gap in college education remains large, with $26 \%$ of whites, but only $15 \%$ of blacks, completing four years of college. In other areas, racial differences have not narrowed at all. The racial gap in unemployment has not changed over the past 25 years, and remains over twice as high for blacks as it is for whites (currently $11.5 \%$ compared to $5.3 \%$ ). And racial differences in homeownership rates have actually increased slightly since $1970{ }^{1}$

While racial inequality remains a pressing problem in the United States, remedies that are both economically effective and politically popular have proved elusive. In particular, racially targeted policies such as affirmative action often elicit strong opposition from whites (Citrin 1996; Gilens, Sniderman, and Kuklinski, 1997; Kinder and Sanders 1996; Steeh and Krysan 1996). Responding to the lack of political support for race-targeted remedies, some observers have called for a "surreptitious" social policy of combating racial inequality through race-neutral programs that will address the needs of poor people of all ethnic and racial groups. William Julius Wilson, for example, approvingly quotes from Vivian Henderson:

The economic future of blacks in the United States is bound up with that of the rest of the nation. Policies, programs, and politics designed in the future to cope with the problems of the poor and victimized will also yield benefits to blacks. In contrast, any efforts to treat blacks separately from the rest of the nation are likely to lead to 
frustration, heightened racial animosities, and a waste of the country's resources and the precious resources of black people. (Wilson 1991, p.477)

The problem, Wilson writes, is that "many white Americans have turned, not against blacks, but against a strategy that emphasizes programs perceived to benefit only racial minorities" (Wilson 1990, p.74). Consequently, in The Truly Disadvantaged, Wilson (1987) urged liberals to adopt a "hidden agenda" of using race-neutral policies to address racial inequality. "The real challenge," he later wrote, "is to develop programs that not only meaningfully address the problems of the underclass but that draw broad support. . . . I now believe that this is best achieved not simply through a combination of targeted and universal initiatives, but through targeted and universal initiatives that are clearly race neutral" (Wilson 1991, p. 478).

The strategy of using race-neutral programs to combat racial inequality has a number of potential shortcomings. Because blacks are disproportionately poor, antipoverty programs should benefit blacks disproportionately. But race-neutral programs are by their nature unable to address the race-specific causes of racial inequality. Poor blacks suffer not only from the problems common to all poor people, but also from the burden of racial discrimination and stereotyping. ${ }^{2}$ While incometargeted programs can help poor blacks, just as they can help the non-black poor, such programs cannot address the racially specific sources of African Americans' economic problems.

In this paper, however, I am concerned not with the practical limitations of race-neutral programs to redress racial inequality, but rather in the nature and extent of public support for such programs. The political argument for race-neutral social programs rests on the belief that public attitudes toward such programs are, to some substantial degree at least, insulated from racial politics. But how plausible is this belief? Do white Americans react to race-neutral antipoverty policies in nonracial terms, or do their racial attitudes also permeate their thinking about programs that target the poor of all races?

The notion that whites' racial views are a stronger influence on race-targeted than on raceneutral antipoverty policies receives some support from previous analyses of public opinion. For example, Bobo and Kluegel (1993) examined the impact of whites' racial attitudes on similar racetargeted and income-targeted social policies. (These policies included government spending to assist 
blacks and the poor, government responsibility for improving the standard of living of blacks and of the poor, and support for enterprise zones and educational spending targeted at blacks and at the poor). Bobo and Kluegel found strong and consistent effects of racial attitudes on race-targeted policies, but weaker and inconsistent effects on support for income-targeted policies. (See also Bobo and Smith (1994) for similar comparisons across a different set of social policies.)

The claim that income-targeted antipoverty policies are somewhat insulated from the impact of white's racial attitudes can also draw support from much of the research on public attitudes toward welfare. Past studies of welfare attitudes have tended either to ignore racial attitudes (e.g., Alston and Dean 1972; AuClaire 1984; Cook and Barrett 1992; Curtin and Cowan 1975; Feagin 1975; Hasenfeld and Rafferty 1989; Williamson 1974) or to assign them a secondary role among the determinants of the public's welfare views (Kluegel and Smith 1986). Rather than racial attitudes, this research has focused on Americans' individualism, their perceived economic self-interest, or their explanations for poverty and perceptions of the poor as the primary influences on attitudes toward welfare.

But other studies have placed more emphasis on racial attitudes in understanding public opposition to welfare. Gilens (1995), Sears and Citrin (1985), and Smith (1987) all found racial views to be important predictors of Americans' attitudes toward welfare. In this paper I take another look at the importance of racial attitudes in understanding opposition to welfare among white Americans, paying particular attention to the problem of distinguishing between attitudes toward blacks, and attitudes toward poor people in general. Blacks compose a disproportionate share of poor people in the United States (currently about 27 percent (U.S. Bureau of the Census 1996). But more to the point, the public

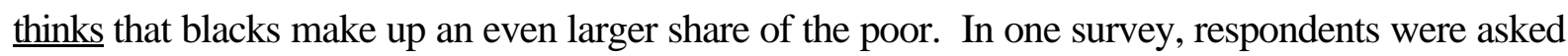
"Of all the people who are poor in this country, are more of them black or are more of them white?", Fifty-one percent of respondents chose black, and only 17 percent white (the remainder said about equal, or had no opinion). In the 1991 National Race and Politics Study (NRPS) analyzed here, respondents were simply asked "What percent of all the poor people in this country would you say are black?" The median guess in response to this question was 50 percent.

Because African Americans constitute a disproportionate share of America's poor, apparently non-racial survey questions taping respondents' attitudes toward the poor may reflect their racial 
attitudes as well. Similarly, survey measures of racial attitudes may reflect not only specific evaluations of and beliefs about blacks, but also beliefs about the poor in general. Because these two sets of attitudes are confounded, the apparent power of each to predict whites' welfare views may be misleading: A strong connection between racial attitudes and welfare views is not in itself compelling evidence that whites think about welfare in racial terms. The belief, for example, that blacks' economic problems are their own fault, may simply be a reflection of a broader judgment that the economically disadvantaged of all races have only themselves to blame. Conversely, a strong connection between respondents' welfare views and their attitudes toward the poor may in fact arise from racial considerations, even if entirely nonracial questions are used to measure attitudes toward the poor.

In this paper, I address the overlap between attitudes toward blacks and toward the poor with a randomized experiment from the NRPS In this experiment, one randomly selected half of the survey respondents were asked questions about a poor black person, while the other half were asked

otherwise identical questions about a poor white person. Because respondents were randomly assigned to the different versions of the questions, the sub-sample of respondents who were asked about a poor black should be nearly identical to the sub-sample asked about a poor white, differing only due to chance variations (and with the large number of respondents to the NRPS, such chance variations between two sub-samples are likely to be quite small). With proper consideration for sampling error, we can estimate the difference in respondents' attitudes toward poor blacks and poor whites by comparing responses to the two different versions of these questions.

\section{Public Attitudes toward Welfare}

Race-neutral antipoverty programs include an array of policies from public housing to Medicaid to the Earned Income Tax Credit. The most prominent among these programs - although not the most costly - consist of what has come to be known simply as "welfare." As it is usually understood, welfare includes means-tested cash-transfer programs for the able-bodied, working-age poor-that is, programs that provide a cash benefit for recipients who must meet a "means test" by showing that they are poor enough to qualify. Understood in this way, welfare includes Aid to Families with Dependent Children (AFDC) and the state-run General Assistance (G.A.) programs. The Food Stamp program 
also serves the able-bodied, working-age poor, but provides a cash-like scrip that can be used to purchase approved foodstuffs.

These means-tested transfer programs, referred to simply as "welfare," represent only a small fraction of social welfare spending, and such programs raise fewer people out of poverty than social insurance programs like Social Security and Unemployment Insurance (Marmor, Mashaw, and Harvey 1990). Nevertheless, both public thinking and elite policy debates over government antipoverty policy focus disproportionately on these means-tested programs. Due, perhaps, to the controversy that surrounds them, welfare programs such as AFDC, G.A., and Food Stamps have become the center of debate over public efforts to help the poor.

Previous efforts to explain Americans' opposition to welfare have often pointed to the economic self-interest of middle-class taxpayers. From this perspective, support for welfare is most likely to be found among lower-income Americans who are welfare recipients themselves, who have friends or family who receive welfare, or who envision the possibility of needing welfare in the future. At the same time, middle- and upper-class taxpayers are expected to oppose welfare out of a desire to reduce their tax burden.

The economic self-interest explanation is widely assumed to be true, and debates over public policy often rest on the assumption that middle-class taxpayers resent paying for programs that benefit only the poor (e.g., Jencks 1992; Skocpol 1990; Skocpol 1991). For example, discussing the politics of welfare in the 1970s and 1980s, Skocpol (1990:63) writes:

This political situation was rooted in a split between people who benefited most from policy changes and people who saw themselves as burdened with higher taxes. Surely many working- and middle-class families have elderly parents or grandparents who gained from Medicare and increases in Social Security, but higher "welfare" transfers to the poor produced no gain for them.

This explanation for opposition to welfare is intuitively plausible, and is bolstered by survey analyses showing that support for welfare is greatest among the least well-off, while opposition increases among those with higher incomes (AuClaire 1984; Cook and Barrett 1992; Curtin and Cowan 1975; Hasenfeld and Rafferty 1989; Williamson 1974). But while this association of economic status and 
welfare attitudes is found consistently by survey analysts, it is often quite modest; many poor Americans nevertheless oppose welfare, while many well-off taxpayers support welfare, despite their apparent selfinterest in cutting welfare spending.

A second widespread explanation for opposition to welfare focuses on individualism. A belief in individual effort and responsibility, and a suspicion of government, have long been viewed as essential elements of American political culture (de Tocqueville [1835] 1969; Hartz 1955; Lipset 1979; McClosky and Zaller 1984; Williams 1956). Along with self- interest, this "culture of individualism" account of anti-welfare sentiment figures prominently in policy debates (e.g., Marmor, Mashaw, and Harvey 1990; Mead 1986). For example, Marmor, Mashaw, and Harvey (1990:240) write:

Commitments to individual and family autonomy, market allocation of most goods and services, and limited and decentralized governance ... tell us much about why we have the welfare state arrangements we do and about the probable direction of future developments. These commitments bound the feasible set of policy initiatives. Once again, this popular belief has received support from survey studies of public attitudes. In a nuanced study of individualism and the welfare state, Feldman and Zaller (1992) argue that individualist values constitute the most common among a variety of ideological orientations that Americans draw upon in thinking about social welfare. Feldman and Zaller's analysis is consistent with that of other researchers who have found that respondents with a greater commitment to individualist beliefs express greater opposition to welfare (Feagin 1975; Hasenfeld and Rafferty 1989; Kluegel and Smith 1986; Williamson 1974).

Explanations for poverty and perceptions of the poor constitute a third influence on public attitudes toward welfare. The key distinction among the many possible explanations for poverty is between accounts that place the blame for poverty on the poor themselves, and accounts that attribute poverty to circumstances beyond the control of the poor. Closely related to these judgments of causal attribution for poverty are perceptions of the poor as either trying hard to overcome their situational disadvantages, or lacking in thrift or effort. When past research has included such measures, they have invariably shown strong associations with attitudes toward welfare. For example, Kluegel and Smith (1986) found explanations for poverty to be the single most important attitudinal predictors of welfare 
views, while Hasenfeld and Rafferty (1989) found an index of attitudes toward the work ethic of the poor to be an important influence on respondents' support for welfare.

In contrast to the attention devoted to economic self-interest, individualism, and beliefs about the poor, racial attitudes have been largely neglected in prior studies of welfare views. Most studies, including some of the most recent and ambitious analyses, have completely omitted racial attitudes from their models of welfare support (Alston and Dean 1972; AuClaire 1984; Cook and Barrett 1992; Curtin and Cowan 1975; Feagin 1975; Hasenfeld and Rafferty 1989; Williamson 1974). When racial attitudes have been examined, researchers have found that negative attitudes toward blacks are associated with greater opposition to welfare (Gilens 1995; Kluegel and Smith 1986; Sears and Citrin 1985; Smith 1987). But as noted above, this research has failed to deal with the central difficulty that measures of racial attitudes are confounded with respondents' broader, non-racial, attitudes toward the poor.

The major hypothesized influences on welfare views, then, consist of economic self-interest, individualism, perceptions of the poor, and racial attitudes. But two additional factors might be thought to shape welfare attitudes, and we will need to take them into account in our analyses. First, partisan identification has long been recognized as an important influence on political policy preferences, and previous research has shown that Republicans express greater opposition to welfare than Democrats (Cook and Barrett 1992). Similarly, conservatives are more likely to oppose welfare than are liberals (Cook and Barrett 1992), so ideological self-identification is also taken into account in examining welfare views.

\section{Data and Measures}

All of the analyses reported here are based on the 1991 NRPS telephone survey and its mailback follow-up. African American respondents are excluded from all of the analyses presented below. This is because racial attitudes clearly play different roles in shaping policy preferences among blacks and among non-blacks. Consequently, separate analyses would be necessary to understand the welfare attitudes of African Americans. (For analyses of blacks' welfare attitudes see Sigelman and 
Welch, 1991 and Gilliam and Whitby, 1989.) This chapter, then, will be based on the 2,022 non-black respondents to the NRPS.

As in previous research, economic self-interest will be measured by family income. Those with higher incomes are expected to express greater opposition to welfare, both because they are less likely to see it as a potential benefit, and because they bear a disproportionate share of its costs in the form of taxes. Although commonly used as an indicator of self-interest, income is clearly not an ideal measure. First, income represents only a "snapshot" of a respondent's economic status; recent changes in income or future expectations might be more directly tied to perceptions about potential benefits from welfare or burdens from taxes. Second, income represents an objective measure of a respondent's social condition, but does not directly tap respondents' perceptions of the potential personal economic costs and benefits of welfare, or the likelihood that those costs or benefits would be realized. Despite these limitations, family income has been shown to be far and away the best objective measure of economic condition for the purpose of assessing welfare views (Gilens 1995), and is virtually the only such measure used in previous studies of this topic (Cook and Barrett (1992) provide the lone exception).

Individualism concerns the proper balance of individual and government responsibility, and is measured quite straightforwardly by a question that asks whether "The government in Washington tries to do too many things that should be left up to individuals and private businesses," with responses expressed on a four-point agree/disagree scale.

To measure perceptions of the poor, respondents' scores on two questions regarding the work ethic of the poor are summed. The first question asks whether "Most people who don't succeed in life are just plain lazy," with responses on a four-point agree/disagree scale. The second asks whether most poor people are poor because "They don't try hard enough to get ahead" or because "They don't get the training and education they need." Respondents who indicate that both explanations for poverty are wrong are given an intermediate score. The resulting index is re-scaled to run from zero for those who reject the belief that poor people are lazy, to one for respondents who are most blaming of the poor. ${ }^{4}$

Perceptions of blacks as lazy are assessed by the difference in respondents' scores on two items from a series of personal characteristics applied to African Americans. The series is introduced as follows: 
Now I'll read a few words that people sometimes use to describe blacks. Of course, no word fits absolutely everybody, but, as I read each one, please tell me using a number from 0 to 10 how well you think it describes blacks as a group. If you think it's a very good description of most blacks, give it a 10. If you feel a word is a very inaccurate description of most blacks, give it a 0 .

The measure of blacks as lazy is constructed by subtracting a respondent's score for "hardworking" from their score for "lazy" and re-scaling to a zero-to-one interval. ${ }^{5}$

Partisanship and ideological self-identification are measured with the standard seven-point scales ranging from strong Democrat to strong Republican, and from strong liberal to strong conservative. Educational attainment is measured on a six-point scale ranging from "Eighth grade or lower" to "Some graduate work or graduate degree"; age is measured in years; marital status is coded 1 for currently married and 0 for not currently married; and region of residence is coded 1 for the South

and 0 for the non-South. ${ }^{6}$ Like the other predictor variables, these measures are all scaled to a range of zero to one.

Respondents' welfare views are measured by (1) a single variable asking whether federal spending for welfare should be increased, decreased, or kept the same, and (2) a summated index of four agree/disagree questions measuring respondents' attitudes toward welfare (see Table 7.1 for full text). Both of these measures are scored from -1 for the most negative views toward welfare to +1 for the most positive.

\section{Findings}

\section{Whites' welfare views}

Whites' ambivalence toward welfare can be seen clearly in Table 7.1, which shows both strong support for the principle of welfare (that is, for direct government payments to poor individuals or families), but also high levels of cynicism toward current welfare recipients, and a clear belief that too much money is being spent on welfare. The first question in the table shows whites' overwhelming support for welfare in principle. Fully 80 percent of white respondents agree that 'When people can't support themselves, the government should help by giving them enough money to meet their basic 
needs." But these same respondents believe that many, or even most, current welfare recipients could manage without government help. Fifty-nine percent agree that "Most people on welfare could get by without it if they really tried."

\section{— TABLE 7.1 ABOUT HERE —}

This cynical view of welfare recipients is balanced somewhat by the more positive belief (subscribed to by fifty-four percent of whites) that "Most people on welfare would rather be working than taking money from the government."7 Finally, 84 percent of white respondents express concern over welfare's financial costs, agreeing that "The high cost of welfare puts too big a burden on the average taxpayer." When the four welfare attitude questions are combined into a welfare attitudes index, ${ }^{8}$ we find that 15 percent of the white respondents express "neutral" attitudes, by agreeing (or disagreeing) equally with the negative and positive questions about welfare. Thirty-five percent of whites express positive welfare attitudes on balance, while 50 percent hold negative attitudes.

A similar distribution of attitudes is found with regard to welfare spending preferences. In this case, 49 percent of whites express negative attitudes, preferring to cut welfare spending. In contrast, only 19 percent think welfare spending should be increased, with the remainder ( 31 percent) preferring to keep spending at its current level.

In sum, we see a pattern of responses consistent with the notion that white Americans view the poor as being composed of two distinct groups: the "deserving poor" and the "undeserving poor" (Katz 1989). This perspective suggests that help should be provided for the truly needy, but that most current welfare beneficiaries are not, in fact, truly needy. Instead, most welfare recipients could get along without welfare if they really tried, and should therefore be counted among the undeserving poor. Consequently, the welfare roles are filled with freeloaders who should be cut off from aid, thereby lifting the undue financial burden from taxpayers.

To what extent does this cynicism toward welfare recipients and desire to trim the welfare roles stem from whites' perception that blacks in particular (who compose a disproportionate share of welfare recipients) fall primarily into the category of the undeserving poor? Or are these attitudes rooted in middle-class whites' concern with their own economic self-interest, in their genuine 
commitment to individual effort and responsibility, or in broader, non-racial perceptions of the poor in general?

\section{Sources of welfare opposition}

To understand the sources of white opposition to welfare, we need to assess the separate and independent effects of each influence on welfare views. In statistical terms, we need to estimate the impact of each variable while "controlling for" the other predictors of whites' welfare attitudes. This is accomplished with ordinary least squares (OLS) regression. Table 7.2 displays the regression results for both welfare spending preferences and the welfare attitudes index. The unstandardized regression coefficients (the "b"s in Table 7.2) indicate the predicted change in respondents' welfare spending preferences or welfare attitudes associated with a 1 unit change in the predictor variable. For example, -.73 in the top left of the table indicates that a one-unit change in perceptions of blacks as lazy (the difference between respondents who most strongly reject this stereotype and those who most strongly accept it) is associated with a .73 unit decrease in support for welfare spending (on the -1 to +1 scale). Also reported are the associated standardized regression coefficients (or "beta"s) which provide similar information but which measure the association between welfare views and each of the predictor variables in standard deviations. ${ }^{9}$

\section{— TABLE 7.2 ABOUT HERE -}

As Table 7.2 shows, the perception of blacks as lazy is the strongest predictor of both whites' welfare spending preferences and their scores on the welfare attitudes index. Whites who fully accept the stereotype of blacks as lazy have predicted scores on welfare spending that are .73 units lower than whites who fully reject this stereotype. This same difference in racial attitudes is associated with a .54unit change in score on the welfare attitudes index. Since both measures of welfare views are scored on a two-point scale (from -1 to +1 ), these coefficients indicate quite a substantial impact.

After perceptions of blacks as lazy, the strongest association with welfare views is the perception that poor people are lazy. White respondents who most strongly subscribe to this 
explanation for poverty express more negative views of welfare, scoring .44 units lower on welfare spending preferences, and .33 units lower on the welfare attitudes index.

The third hypothesized influence on welfare views_-individualism—is also related to both welfare spending preferences and the welfare attitudes index, although less strongly than are perceptions of blacks and of the poor. White respondents who strongly agree that the government "tries to do too many things that should be left up to individuals and private business" score .27 units lower on welfare spending preferences and .22 units lower on the welfare attitudes index.

Table 7.2 also shows that family income, our indicator of economic self-interest, is related to welfare spending preferences (with a coefficient of -.25) but not to the welfare attitudes index $(b=.00)$. This difference supports the validity of income as an indicator of economic self-interest, as it appears that whites with higher incomes (and therefore higher taxes) do not hold more negative views of welfare or welfare recipients, but are nevertheless less likely to favor welfare spending. Even with regard to welfare spending, however, the impact of family income is rather modest: A difference of $\$ 60,000$ in income (between the lowest and the highest categories) is associated with a .25 unit difference on the two-point welfare spending scale (scored from -1 to +1 ).

In addition to these four influences on welfare views, Table 7.2 shows that opposition to welfare spending is higher among older white respondents, but that age is unrelated to the welfare attitudes index. Repeating the pattern found for family income, this difference suggests that age influences welfare policy preferences not because older white respondents hold different attitudes toward those on welfare, but because they see their self-interest as better served by cutting welfare spending. Perhaps this should not be surprising, since welfare programs are most closely associated with young families, and the most prominent welfare program, AFDC, is restricted to families with dependent children. In contrast, programs that direct more of their resources to the elderly, including means-tested programs such as Medicaid or Supplemental Security Income (S.S.I.), are not often thought of as "welfare."

The remaining predictor variables in Table 7.2 show weak-to-moderate relationships with the welfare measures. White Democrats are more likely than Republicans to support welfare spending while married respondents express greater opposition than those not married. Opposition to welfare as 
measured by the welfare attitudes index is also higher among married whites, while liberals and those with higher education are more supportive than their conservative or less educated counterparts.

Most of the predictors in Table 7.2 show some relationship to white Americans' welfare views, but only beliefs about the character of blacks and of poor people and respondents' general preferences for individual versus government responsibility have strong and consistent influences on both measures of welfare, and of these, perceptions of blacks as lazy emerges as the single most powerful predictor of white Americans' welfare views. These results suggest that the popular belief that welfare is a "race coded" issue is warranted; whatever other reasons whites may have for opposing welfare, their negative views of blacks appear to constitute an important factor in generating that opposition.

It is, perhaps, no great shock to find that the belief that blacks are lazy can generate opposition to welfare among whites. But two things must be kept in mind to fully appreciate the importance of this finding. First, it is not just poor blacks, or blacks on welfare, who were asked about; instead respondents were instructed to indicate how well "lazy" and "hard working" describe most blacks. This suggests that not only are whites' evaluations of welfare steeped in racial considerations, but that these considerations appear to involve little distinction between the minority of blacks who receive welfare and the majority who do not.

The second thing that we must keep in mind is that the impact of racial views on welfare support is even stronger than the impact of views about the poor in general. Remarkably, whites' perceptions of blacks as lazy are more important in shaping opposition to welfare than their perceptions of poor people as lazy. Once again, this suggests that the welfare debate has become so thoroughly racialized, that what matters most to the white public is perceptions of a single sub-group of welfare recipientsblacks. Although only $36 \%$ percent of current welfare recipients are black (U.S. House of Representatives 1996, p.474), beliefs about blacks appear to dominate whites' thinking when it comes to evaluating welfare.

\section{Measuring Racial Attitudes with a Survey-Based Experiment}


As indicated above, one difficulty in analyzing the influences on Americans' welfare views is that attitudes toward blacks are confounded with attitudes toward the poor. In the analyses presented above, I attempted to deal with this problem by using OLS regression to statistically "hold constant" attitudes toward the poor (along with all the other variables in the model) in order to estimate the independent impact of respondents' racial attitudes. (Similarly, of course, racial attitudes, along with the other predictor variables, were held constant when estimating the impact of attitudes toward the poor.) This is the standard technique for dealing with correlated predictors, and is clearly an important improvement over models of welfare views that include only racial attitudes or attitudes toward the poor but not both. Nevertheless, OLS regression and related statistical models are necessarily imperfect solutions to this problem.

In the analyses in Table 7.2, perceptions of the work ethic of blacks and of the poor are not assessed with identical questions. Perceptions of blacks were ascertained by asking respondents to rate the applicability of "lazy" and "hardworking" to "most blacks," while perceptions of the poor were measured by questions asking whether "Most people who don't succeed in life are just plain lazy," and whether most poor people are poor because "They don't try hard enough to get ahead" or because "They don't get the training and education they need."

Although these questions appear to be valid measures of perceptions of blacks and of the poor, we would prefer to have strictly identical measures to assess their importance in shaping welfare attitudes. Without parallel questions, we cannot be sure that our survey measures are serving as adequate statistical controls for each other. For example, if the measure of racial perceptions is a more reliable measure than the index of perceptions of the poor, or if it better taps the particular attitudinal dimension relevant to welfare views, than racial attitudes may appear to have more explanatory power than perceptions of the poor. Without parallel questions, we cannot be sure that we have successfully "purged" the measure of racial attitudes of its non-racial components, nor can we be sure that the estimated impact of attitudes toward the poor does not still reflect respondents' racial perceptions, despite our inclusion of the racial attitudes measure in the regression model.

Unfortunately, we cannot simply ask respondents to evaluate both blacks and poor people using the same questions, due to the social desirability and consistency pressures that operate within the 
interview setting (Schuman and Presser 1981). Because social norms of equality apply to racial issues, respondents may feel pressured to provide the same responses to questions about blacks and about whites. Thus if white respondents acknowledge their belief that black welfare recipients are lazy, they face a pressure to say that white welfare recipients are lazy as well, if asked on a subsequent question. Alternatively, if they first indicate that whites on welfare would prefer to be working, they might feel pressured to respond that African American welfare recipients would rather be working too.

In order to gauge white respondents' true views of poor blacks and poor whites with identical questions, I use an experimental manipulation in which half the respondents are asked only about blacks and the other half are asked otherwise identical questions which refer instead to whites. Because each respondent is asked only about one racial group, consistency pressures are absent. Thus, rather than compare two questions (or sets of questions) asked of the same respondent, I compare the answers given by two different groups of respondents. But because respondents are randomly assigned to the "black" or "white" versions of these questions, the two groups can be assumed to be identical in every way, within the limits of sampling error.

This technique combines the advantages of the randomized experiment with those of the sample survey (see Piazza, Sniderman, and Tetlock 1989). By randomly assigning respondents to different question "treatments" we ensure that differences in responses result from differences in the questions asked, and since the random assignment is uncorrelated with respondents' characteristics we need not worry that differences in responses to poor blacks and poor whites are confounded with other factors such as education, region, or political attitudes. By embedding this experiment within a large-scale national survey, we also retain the ability to generalize to the American population at large, an ability that is severely limited in the typical small-scale experiment.

By means of a "survey experiment" we can reveal something of the thought process or judgmental heuristic (Sniderman, Brody, and Tetlock 1991) respondents use in evaluating welfare. When white Americans assess welfare in general, or identify their preferences with regard to welfare spending, are they thinking more about black welfare recipients, white welfare recipients, or both equally? 
In the "welfare mother" experiment respondents are asked their impressions of a welfare recipient described as either a black or white woman in her early thirties, who has a ten year old child and has been on welfare for the past year. ${ }^{10}$ Respondents are first asked how likely it is that the woman described will try hard to find a job, and second, how likely it is that she will have more children in order to get a bigger welfare check. Half of the respondents are randomly assigned to the "black version" of the question and the other half the "white version." For this analysis, the responses to the questions about jobs and children are combined into an index of welfare mother stereotypes, ${ }^{11}$ with those saying it is very unlikely that the welfare mother will look for a job and very likely that she will have more children receiving the highest scores.

If respondents are thinking more about black welfare mothers when they offer their overall views of welfare, then we would expect the black version of the welfare mother experiment to be more strongly related to welfare views than the white version. Most importantly, because the two versions of these questions are identical except for the race of the hypothetical welfare mother, and because respondents were randomly assigned to one version of the questions or the other, we can feel certain that if the two versions differ in their ability to predict whites' welfare views, this difference reflects the influence of respondents' racial attitudes.

To assess the relative importance of black and white welfare mother stereotypes I repeat the regression analyses of Table 7.2 using responses to the black and white versions of the welfare mother experiment in place of the measures of attitudes toward blacks and toward the poor. Because different groups of respondents were asked the black and white versions of the welfare mother questions, separate analyses are conducted for each of the two experimental groups. ${ }^{12}$ Tables 7.3A, 7.3B, and 7.3C show the results of these analyses in predicting whites' welfare spending preferences, their scores on the welfare attitudes index, and their perceptions of the poor as lazy (using the same index that was used as a predictor variable in Table 7.2).

\section{— TABLES 7.3A, 7.3B, and 7.3C ABOUT HERE -}

The results from each of these analyses, based on the three different aspects of attitudes toward welfare and poverty, are the same: Whites' perceptions of black welfare recipients are clearly more important predictors than their perceptions of white welfare recipients. Table 7.3A shows that the black 
version of the welfare mother experiment predicts whites' welfare spending preferences at -.55 while the white version produces an analogous coefficient of -.32. With regard to the welfare attitudes index, the black version of these questions again proves to be the better predictor, with a coefficient of -.49 compared with -.28 for the white versions. Finally, if we use these same questions to predict respondents' perceptions of the poor as lazy, we find that once again whites attitudes toward the poor are dominated by their views of poor blacks, not poor whites. In this case the black version of the welfare mother experiment produces a coefficient of .36 compared to only .14 for the white version. This last finding confirms the suspicion that the ostensibly race-neutral question about the work ethic of the poor which was used as a predictor in Table 7.2 is not race-neutral at all, but is in fact primarily reflective of respondents' perceptions of poor blacks.

The results of the welfare mother experiment are unambiguous. Whites' perceptions of black welfare mothers are consistently better predictors of their overall views on welfare and poverty than their perceptions of white welfare mothers. For the three attitudinal measures used in Tables 7.3A through 7.3C, the black version of the welfare mother questions outperforms the white version by factors of 1.7, 1.8, and 2.6 (each of the black/white comparisons is statistically significant at the .05 level). ${ }^{13}$

Clearly, perceptions of black welfare recipients play a different, and more important, role in shaping white Americans' thinking about poverty and welfare than do perceptions of white welfare recipients. Do white Americans also hold more negative views of black welfare recipients? The welfare mother experiment is of only limited value in answering this question, because the black and white welfare mothers are described identically and in considerable detail. Both the black and white welfare recipients are described as being in their early thirties, with one child, and as having been on welfare for the past year. In contrast, respondents may hold rather different impressions of the "average" black and white welfare recipients, thinking, for example, that black welfare recipients are younger, have more children, or have been on welfare for longer. Thus the degree of positive or negative response to theses hypothetical welfare mothers can tell us only how white respondents view similarly described black and white welfare mothers, not how they view what they regard as "typical" black and white welfare recipients. 
With this limitation in mind, Table 7.4 shows that white respondents do not seem to apply a racial double standard; black and white welfare mothers—when similarly described—elicit similar levels of positive and negative imagery from the white public. As the bottom panel of Table 7.4 indicates, $39 \%$ of white respondents offered negative reactions to both questions about the hypothetical white welfare mother, while a nearly identical $38 \%$ offered negative reactions to both questions about the black welfare mother. ${ }^{14}$ Similarly, $22 \%$ of whites had positive reactions to both questions when the hypothetical welfare mother was black, while $25 \%$ offered positive reactions to both questions in response to a white welfare mother.

\section{— TABLE 7.4 ABOUT HERE —}

\section{The Salience of Negative Racial Stereotypes}

Both the traditional regression model shown in Table 7.2 and the results of the survey experiment reported in Table 7.3 show that white Americans' welfare views are clearly not "raceneutral" expressions of their economic self-interest, their commitment to individualism, or their evaluations of poor people. Instead, whites' views are, to a remarkable degree, rooted in their perceptions of blacks in general and of black welfare recipients in particular.

The racial character of whites' response to ostensibly race-neutral welfare programs is significant in itself. But the most pressing question is whether the racialized nature of whites' thinking about welfare results in decreased levels of support. It might appear from the similar responses to the black and white welfare mothers shown in Table 7.4 that this is not the case. After all, if whites' views of white welfare mothers are no more positive than their views of black welfare mothers, it might appear not to matter that whites' welfare views are dominated by their perceptions of blacks.

But the similarity of whites' evaluations of black and white welfare mothers does not mean that racial considerations do not impact support for welfare, because the consequences of holding negative beliefs about black and white welfare mothers are not the same. Figure 7.1 shows that, as expected, respondents with positive perceptions of welfare mothers express greater support for welfare than those with negative views. But there is a racial asymmetry apparent in this figure. The welfare attitudes of 
white respondents with positive perceptions of white welfare mothers are the same as those with positive perceptions of black welfare mothers (.10 versus .09; a statistically nonsignificant difference), and the welfare attitudes of those with neutral views of white and black welfare mothers are the same (.03 versus .01; also statistically nonsignificant). However, the consequence of holding negative perceptions depends on whether the perceptions are of white welfare recipients or black white welfare recipients. Negative perceptions of black welfare mothers are associated with significantly more negative views of welfare in general than are negative perceptions of white welfare mothers (-.25 versus -.10; statistically significant at $\mathrm{p}<.0002)$.

\section{— FIGURE 7.1 ABOUT HERE —}

We saw in Tables 7.2 and 7.3 that racial attitudes figure prominently in whites' evaluations of welfare and that perceptions of black welfare mothers are stronger influences on whites' welfare views than perceptions of white welfare mothers. Figure 7.1 reveals just why this is so. The greater power of perceptions of black welfare mothers to shape whites respondents' welfare views comes from the particular salience of negative images of blacks. Positive images of black or white welfare mothers are associated with mildly positive scores on the welfare attitudes index, while neutral perceptions of black or white welfare mothers are associated with neutral scores. Negative perceptions of white welfare mothers also show a modest impact on welfare attitudes, but negative perceptions of black welfare mothers have a dramatically stronger impact on whites' welfare views. For many whites, the image of a black welfare mother has become a "condensation symbol" (Edelman 1985) of what is wrong with America's welfare system, and, indeed, of what is wrong with American blacks.

\section{Conclusions}

In this paper I explored one aspect of the claim that race-neutral antipoverty policies can be expected to garner greater political support because they are less vulnerable to racial politics. Focusing on welfare - a prominent component of current antipoverty programs - I examined the role of racial attitudes in shaping policy preferences and overall support among white Americans. Both conventional modeling techniques and a survey-based randomized experiment showed that whites' responses to 
welfare, and their thinking about the poor in general, strongly reflect their views of blacks. First, using a traditional regression model, I compared the predictive power of economic self-interest, attitudes toward individualism, beliefs about the poor in general, and perceptions of blacks as lazy, and found the last of these to be the most important influence on whites' welfare spending preferences and their attitudes toward welfare. Then, using a randomized experiment to disentangle respondents' attitudes toward poor blacks and poor whites, I confirmed the importance of the specifically racial elements of white Americans' thinking about welfare and poverty, showing that whites' perceptions of black welfare recipients are considerably more important than their perceptions of white welfare recipients in shaping their views on welfare and their perceptions of the work ethic of the poor. Finally, I showed that negative images of black welfare mothers have a particularly strong impact on whites' attitudes toward welfare, far exceeding the influence of negative images of white welfare mothers, as well as the influence of positive images of either black or white welfare recipients.

Although blacks constitute barely one out of three welfare families, ${ }^{15}$ perceptions of black welfare mothers - especially negative perceptions - appear to dominate whites' evaluations of welfare recipients and their preferences with regard to welfare spending. This negative "racialization" of welfare calls into question the "hidden agenda" strategy for fighting racial inequality. It is clear that simply making benefits available to all poor Americans is not enough to divorce antipoverty programs from racial politics; as this chapter has shown, even race-neutral antipoverty policies can fall prey to racial stereotyping.

To the extent that antipoverty programs become associated with African Americans, and in particular, to the extent to that such programs evoke the public's negative stereotypes of blacks, support among whites will remain limited. Welfare seems especially susceptible to just this kind of negative racial politics. First, welfare has become strongly associated with blacks, so much so that many now consider welfare to be a "codeword" for race (Edsall and Edsall 1991, Jamieson 1992). Just as importantly, welfare evokes precisely the kinds of negative stereotypes that still afflict African Americans.

Over the past few decades, whites' racial attitudes have become markedly more sympathetic along many dimensions (Carmines and Champagne 1990; Schuman, Steeh, and Bobo 1985). 
Nevertheless, negative stereotypes of blacks remain widespread, and the belief that blacks lack commitment to the work ethic appears to be an especially widespread perception among white Americans. When the General Social Survey asked respondents to rate blacks and whites with regard to six different social characteristics, blacks were viewed more negatively on each one (Davis and Smith 1994). White respondents perceived blacks to be more violent, less patriotic, less intelligent, poorer, lazier, and more likely to prefer living off welfare rather than be self-supporting. Of the six characteristics, however, the preference for welfare over self-support elicited by far the largest difference between the qualities attributed to blacks and those attributed to whites. Using a seven-point scale in which one side indicates that the group being evaluated prefers to live off welfare and the other side indicates the group prefers to be self-supporting, $74 \%$ of white respondents placed whites as a group on the "self-supporting" side of the scale, but only 13\% placed blacks on this side of the scale.

As long as African Americans make up a disproportionate share of the poor it is unlikely that antipoverty policy can be fully divorced from racial politics (and this separation is made all the more unlikely by the public's exaggerated perception that blacks constitute the majority of the poor). However, whites' race-based opposition to antipoverty programs is not rooted in a general antipathy toward blacks, but rather in the more specific belief that many African Americans lack commitment to the work ethic. In the analysis in this chapter, the perception of blacks as lazy proved to be the strongest predictor of whites' welfare views, and in previous research comparing many dimensions of racial attitudes, the perception that blacks' lack commitment to the work ethic emerged as the most powerful influence on whites' thinking about welfare (Gilens 1995).

If white opposition to antipoverty programs reflected a general antipathy toward blacks, than any program perceived to benefit primarily African Americans would be unlikely to gain wide public support. But if the most relevant racial attitudes involved are more narrowly focused, as appears to be the case, then the vulnerability of antipoverty programs should vary, depending on the degree to which they evoke the relevant negative stereotypes of blacks. Those antipoverty programs (like welfare) that are thought to undermine the work ethic, or reward those who are too lazy or undisciplined to support themselves, should be most vulnerable to racial politics, while those that are viewed as enhancing self- 
sufficiency—even if strongly identified with minorities—should sustain more support among the white public.

Of existing government antipoverty programs, welfare and food stamps are clearly associated with blacks and consistently receive the lowest levels of public support. But there are other programs which are just as strongly associated with racial minorities that receive much greater support from the public. For example, in one survey $67 \%$ of white respondents indicated that they believed the majority of food stamp recipients are racial minorities while $80 \%$ of white respondents believed this to be true for public housing (Sanders 1996). Yet public housing programs are far more popular than food stamps: While only $36 \%$ of Americans object to cutting food stamps in order to balance the federal budge, 59\% oppose cuts in public housing for this purpose (Times Mirror 1995). Furthermore, survey data show that some of the most popular antipoverty programs are among those most strongly associated with minorities. Both Head Start and job training programs receive overwhelming support from the public, with majorities saying we should increase spending in both these areas. ${ }^{16}$ Yet $59 \%$ of whites believe that most children enrolled in Head Start classes are minorities, and $68 \%$ think that minorities account for most of those in job training programs (Sanders 1996).

While antipoverty programs cannot be divorced from racial politics simply by adopting a raceneutral benefit structure, it is equally clear that a program's strong association with racial minorities does not preclude high levels of public support. As we saw in this chapter, whites' racial attitudes can and do produce opposition to some antipoverty programs, despite these programs' race-neutral structure; the "hidden agenda," it appears, is not very well hidden at all. But all antipoverty programs are not equally vulnerable to the anti-black attitudes that so strongly impact whites' thinking about welfare. Programs that are seen as enhancing the ability of poor people to support themselves, rather than rewarding the lazy with government "handouts," do not evoke the same negative racial imagery. Unlike welfare, public housing can be viewed as a supplement to, not a substitute for, self-support; after all, public housing tenants pay rent for their apartments. And Head Start and job training programs can be seen as an investment in individuals which, it is hoped, will pay off by allowing them to support themselves. These programs are seen as helping people help themselves, not undermining their motive to work, and as a result are less vulnerable to the politics of racial stereotyping. 
The impulse behind the "hidden agenda" is not wrong. Programs that limit their benefits to racial minorities clearly face perceptions of unfairness that income-targeted programs do not. But public perceptions of poverty are now so steeped in racial thinking that even race-neutral antipoverty programs are strongly associated with African Americans. An effective strategy, from the standpoint of attracting popular support, is not to promote programs that will surreptitiously help blacks without the public noticing, but rather to support programs that the public will gladly endorse, knowing full well that a disproportionate share of the benefits will accrue to African Americans. The popularity of Head Start, job training, and public housing attest to the feasibility of this agenda. The challenge now is to enlist the public, and the country's political elites, in the effort to improve and expand such programs. 


\section{Chapter 7 Endnotes}

1. For statistics on the racial differences cited see, for income: U.S. Census Bureau web page (http://www.census.gov), Table P-2a, Median Income in Current Dollars for 1970 and 1994; for education: U.S. Census Bureau web page (http://www.census.gov), March Current Population Survey for 1970 and 1995; for unemployment: U.S. Bureau of the Census 1995, p.400; for homeownership: U.S. Bureau of the Census 1995, p.733.

2. For evidence of racial discrimination in housing see Massey and Denton, 1993; for evidence of employment discrimination see Kirschenman and Neckerman, 1991.

3. CBS/New York Times National Survey, March 1982.

4. Cronbach's alpha for the scale measuring perceptions of the work ethic of the poor is .38.

5. Cronbach's alpha for the scale measuring perceptions of blacks as lazy is .35.

6. The South is defined as Alabama, Arkansas, Florida, Georgia, Louisiana, Mississippi, North Carolina, South Carolina, Texas, and Virginia.

7. The willingness to agree to both of these apparently contradictory statements could result from the perception among some white respondents that most welfare recipients could get along without welfare, but at an even lower standard of living, and while they would prefer to be working, are not willing to make the financial sacrifice that leaving welfare would entail.

Alternatively, acquiescence bias, or the tendency among some respondents to agree to any statement (or at least any statement about which they have mixed feelings or are unsure), could result in majority support for each of these beliefs about welfare recipients.

8. Cronbach's alpha for the four-item Welfare Attitudes Index is .61.

9. The standard deviation is a measure of the average or typical amount of spread or variation in the distribution of a variable. Thus the standardized coefficients therefore reflect the amount of change in welfare attitudes associated with a typical or average amount of change in each of the predictor variables.

10. In addition, the hypothetical welfare mother is described to one random sub-sample as a high school graduate and to the other random sub-sample as a high school drop out. This experimental manipulation is orthogonal to the race of the hypothetical welfare mother, so that one-quarter of the respondents receive the "black drop out" version, one-quarter the "black graduate" version, one-quarter the "white drop out" version, and one-quarter the "white graduate" version. For the analyses in this chapter, the two educational variations are combined.

11. Cronbach's alpha for the welfare mother index is .61.

12. Randomized assignment to experimental treatment groups (in this case the black and white versions of the welfare mother experiment) is used to ensure that respondents assigned to each group are as similar as possible in every way except for the version of the welfare mother questions they are asked. But in any finite size sample some differences between randomly constructed groups are likely to emerge. To decrease the likelihood that such randomly occurring differences between the experimental groups are responsible for the observed effects 
of the black and white welfare mother questions, the variance/covariance matrices of the other variables included in the analyses in Tables 7.3A, 7.3B, and 7.3C are constrained to be equal for the two experimental groups.

13. Significance levels for the differences between the regression coefficients produced by the black and white versions of the welfare mother experiment, using one-tailed tests, are $.05, .007$, and .03 for welfare spending preferences, welfare attitudes, and perceptions of the poor as lazy, respectively.

14. The positive views of welfare recipients expressed by many white respondents may reflect the description of the welfare mother in our experiment. She is described as being in her early thirties, having only one child who is ten years old, and having been on welfare only one year. In addition, for a random half of the respondents, the welfare mother is described as being a high school graduate (see note 10). Therefore she does not appear to be a "chronic" welfare recipient, and may have been perceived more sympathetically by respondents than would be the case for other (more typical) welfare recipients.

15. Currently $36 \%$ of families receiving AFDC are headed by African Americans (U.S. House of Representatives 1996).

16. For example, $61 \%$ of respondents to the 1990 General Social Survey said spending for Head Start should be increased, while only $5 \%$ wanted spending for Head Start cut (Davis and Smith, 1994). In another recent poll, $60 \%$ of respondents said they would be willing to pay higher taxes in order to increase spending on job training programs, compared to $37 \%$ who were not willing to pay higher taxes for this purpose (NBC News 1994). 


\section{Chapter 7 References}

Alston, Jon P., and K. Imogene Dean. 1972. "Socioeconomic Factors Associated with Attitudes Toward Welfare Participants and the Causes of Poverty." Social Service Review 46(March):13-23.

AuClaire, Philip Arthur. 1984. "Public Attitudes Toward Social Welfare Expenditures." Social Work 29(March-April):139-144.

Bobo, Lawrence and James R. Kluegel. 1993. "Opposition to Race-Targeting: Self-Interest, Stratification Ideology, or Racial Attitudes?” American Sociological Review 58(August):44364.

Bobo, Lawrence and Ryan A. Smith. 1994. "Antipoverty Policy, Affirmative Action, and Racial Attitudes." Pp. 365-395 in Confronting Poverty: Prescriptions for Change, Sheldon H. Danziger, Gary D. Sandefur, and Daniel H. Weinberg, eds. Cambridge: Harvard University Press.

Carmines, Edward G. and Richard A. Champagne Jr. 1990. "The Changing Content of American Racial Attitudes.” In Research in Micropolitics vol. 3, Samuel Long, ed. Greenwich, CT: JAI Press.

Citrin, Jack. 1996. "Affirmative Action in the People's Court.” The Public Interest, n.122, 39-48.

Cook, Fay Lomax and Edith J. Barrett. 1992. Support for the American Welfare State. New York: Columbia University Press.

Curtin, Richard T., and Charles D. Cowan. 1975. "Public Attitudes Toward Fiscal Programs.” In 1972-1973 Surveys of Consumers, ed. Burkhard Strumpel. Ann Arbor: University of Michigan, Institute for Social Research.

Davis, James Allan and Tom W. Smith. 1994. General Social Surveys, 1972-1994 [machine readable data file]. Chicago: National Opinion Research Center.

de Tocqueville, Alexis. 1969 [1835]. Democracy in America. Garden City, New York: Anchor Books. Edelman, Murray. 1985. The Symbolic Uses of Politics. Urbana: University of Illinois Press.

Feagin, Joe R. 1975. Subordinating the Poor: Welfare and American Beliefs. Englewood Cliffs, NJ: Prentice-Hall.

Feldman, Stanley, and John Zaller. 1992. "The Political Culture of Ambivalence: Ideological Responses to the Welfare State." American Journal of Political Science 36(February):268-307.

Gilens, Martin. 1995. "Racial Attitudes and Opposition to Welfare." The Journal of Politics 57(November):994-1014.

Gilens, Martin, Paul M. Sniderman, and James. H. Kuklinski. 1997. "Affirmative Action and the Politics of Realignment.” British Journal of Political Science (forthcoming).

Gilliam, Franklin D., Jr. and Kenny J. Whitby. 1989. "Race, Class and Attitudes Toward Social Welfare Spending: An Ethclass Interpretation.” Social Science Quarterly 70(March):88-100.

Hartz, Louis. 1955. The Liberal Tradition in America. San Diego: Harcourt Brace Jovanovich.

Hasenfeld, Yeheskel, and Jane A. Rafferty. 1989. "The Determinants of Public Attitudes Toward the Welfare State." Social Forces 67(June):1027-1048.

Jencks, Christopher. 1992. Rethinking Social Policy. Cambridge: Harvard University Press.

Katz, Michael B. 1989. The Undeserving Poor. New York: Pantheon Books. 
Kinder, Donald R. and Lynn M. Sanders. 1996. Divided by Color: Racial Politics and Democratic Ideals in the American Republic. Chicago: University of Chicago Press.

Kirschenman, Joleen and Kathryn M. Neckerman. 1991. "WWe'd Love to Hire Them, But . . .' The Meaning of Race for Employers." Pp. 203-234 in The Urban Underclass, Christopher Jencks and Paul E. Peterson, eds. Washington, D.C.: The Brookings Institution.

Kluegel, James R., and Eliot R. Smith. 1986. Beliefs About Inequality: Americans' Views of What is and What Ought to Be. New York: Aldine de Gruyter.

Lipset, Seymour Martin. 1979. The First New Nation. New York: Norton.

Marmor, Theodore R., Jerry L. Mashaw, and Philip L. Harvey. 1990. America's Misunderstood Welfare State. New York: Basic Books.

Massey, Douglas S. and Nancy A. Denton. 1993. American Apartheid: Segregation and the Making of the Underclass. Cambridge: Harvard University Press.

McClosky, Herbert, and John Zaller. 1984. The American Ethos. Cambridge: Harvard University Press.

Mead, Lawrence M. 1986. Beyond Entitlement. New York: Free Press.

NBC News. 1994. NBC News/Wall Street Journal Survey, conducted June 10-14.

Piazza, Thomas, Paul M. Sniderman, and Philip E. Tetlock. 1989. "Analysis of the Dynamics of Political Reasoning: A General-Purpose Computer- Assisted Methodology.” In Political Analysis, ed. James A. Stimson. Ann Arbor: University of Michigan Press.

Sanders, Lynn M. 1996. "Racialized Interpretations of Economic Reality.” Prepared for the Annual Meetings of the American Political Science Association, San Francisco, August 29-September 1.

Schuman, Howard, and Stanley Presser. 1981. Questions and Answers in Attitude Surveys. San Diego: Academic Press.

Schuman, Howard, Charlotte Steeh, and Lawrence Bobo. 1985. Racial Attitudes in America: Trends and Interpretations. Cambridge: Harvard University Press.

Sears, David O. and Jack Citrin. 1985. Tax Revolt. Cambridge: Harvard University Press.

Sigelman, Lee, and Susan Welch. 1991. Black Americans' Views of Racial Inequality. Cambridge: Cambridge University Press.

Skocpol, Theda. 1990. "Sustainable Social Policy: Fighting Poverty Without Poverty Programs." The American Prospect 2(Summer):58-70.

. 1991. "Targeting Within Universalism." In The Urban Underclass, ed. Christopher Jencks and Paul E. Peterson. Washington, D.C.: The Brookings Institution.

Smith, Tom W. 1987. "That Which We Call Welfare by Any Other Name Would Smell Sweeter: An Analysis of the Impact of Question Wording on Response Patterns." Public Opinion Quarterly 51(Spring):75-83.

Sniderman, Paul M., Richard A. Brody, and Philip E. Tetlock. 1991. Reasoning and Choice: Explorations in Political Psychology. Cambridge: Cambridge University Press.

Steeh, Charlotte and Maria Krysan. 1996. "Trends: Affirmative Action and the Public, 1970-1995."

Public Opinion Quarterly 60(Spring):128-158.

Times Mirror. 1995. Times Mirror Company Survey, conducted August 17. 
U.S. Bureau of the Census. 1995. Statistical Abstract of the United States: 1992. Washington, D.C.: U.S. Government Printing Office.

U.S. Bureau of the Census. 1996. "Historical Poverty Tables - Table 14" Census Bureau Web Site, http://www.census.gov/hhes/poverty/histpov/hstpov14.html.

U.S. House of Representatives. 1996. Background Material and Data on Programs Within the Jurisdiction of the Committee on Ways and Means. Washington, D.C.: U.S. Government Printing Office.

Williams, Robin M. 1956. American Society. New York: Knopf.

Williamson, John B. 1974. "Beliefs About the Motivation of the Poor and Attitudes Toward Poverty Policy." Social Problems 21(June):634-648.

Wilson, William Julius. 1987. The Truly Disadvantaged. Chicago: University of Chicago Press. . 1990. "Race-Neutral Programs and the Democratic Coalition." The American Prospect 1(Spring):74-81. . 1991. "Public Policy Research and The Truly Disadvantaged." Pp. 460-482 in The Urban Underclass, Christopher Jencks and Paul E. Peterson, eds. Washington, D.C.: The Brookings Institution. 
Table 7.1

\section{Whites' Welfare Attitudes and Welfare Spending Preferences}

$\begin{array}{llccc}\text { Welfare Attitudes } & \begin{array}{l}\text { Agree } \\ \text { Strongly }\end{array} & \begin{array}{c}\text { Agree } \\ \text { Somewhat }\end{array} & \begin{array}{c}\text { Disagree } \\ \text { Somewhat }\end{array} & \begin{array}{c}\text { Disagree } \\ \text { Strongly }\end{array}\end{array}$

When people can't support themselves, the government should help by giving them enough money to meet their basic needs.

Most people on welfare could get by without it 17

$29 \%$

$51 \%$

$16 \%$

$5 \%$

if they really tried.

Most people on welfare would rather be working than taking money from the government.

The high cost of welfare puts too big a burden on the average taxpayer.

\begin{tabular}{ccc} 
Positive & Neutral & Negative \\
Attitudes & $\underline{\text { Attitudes }}$ & $\underline{\text { Attitudes }}$ \\
\hline
\end{tabular}

Welfare Attitudes Index

Suppose you had a say in making up the federal budget, would you prefer to see more $19 \%$ $31 \%$ $49 \%$ spent, less spent, or the same amount of money spent on welfare as it has been? 
Table 7.2

\section{Regression Analysis of Whites' Welfare Spending Preferences and Welfare Attitudes}

\begin{tabular}{|c|c|c|c|c|c|c|}
\hline & $\underline{\text { Wel }}$ & fare Spenc & ding & Welfar & Attitude & es Index \\
\hline & $\underline{\mathrm{b}}$ & s.e. of $b$ & beta & $\underline{b}$ & s.e. of b & beta \\
\hline Blacks are lazy & -.73 & .13 & $-.17 * * *$ & -.54 & .06 & $-.27 * * *$ \\
\hline Poor people are lazy & -.44 & .10 & $-.14 * * *$ & -.33 & .04 & $-.22 * * *$ \\
\hline Individualism & -.27 & .08 & $-.10 * *$ & -.22 & .04 & $-.17 * * *$ \\
\hline Family income & -.25 & .09 & $-.10 * *$ & .00 & .04 & .00 \\
\hline Age & -.28 & .11 & $-.08 *$ & .09 & .05 & .05 \\
\hline Party identification (high=Democrat) & .18 & .05 & $.11 * * *$ & .04 & .02 & .06 \\
\hline Married $(1=$ yes, $0=$ no) & -.13 & .05 & $-.08 *$ & -.06 & .02 & $-.08 * *$ \\
\hline Ideology (high=liberal) & .07 & .06 & .04 & .07 & .03 & $.07 *$ \\
\hline Education & .05 & .11 & .01 & .10 & .05 & $.06 *$ \\
\hline Region (1=south, $0=$ non-south) & -.01 & .06 & .00 & .04 & .03 & .04 \\
\hline $\mathrm{R}^{2}$ & & .13 & & & .24 & \\
\hline $\mathrm{N}$ & & 988 & & & 983 & \\
\hline
\end{tabular}

Note: $b$ is the unstandardized regression coefficient; s.e. of $b$ is the standard error of the regression coefficient; beta is the standardized regression coefficient. All independent variables are recoded to a 0 to 1 range. Welfare spending indicates respondents' preferences for increasing, maintaining, or decreasing spending on welfare, scored $+1,0$ and -1 , respectively. The welfare attitudes index is comprised of four variables measuring respondents' attitudes toward welfare (see Table 1 for question wording), with the index scored from -1 for the most negative to +1 for the most positive attitudes. 
Table 7.3A

\section{Whites' Welfare Spending Preferences as Predicted by Perceptions of Black and White Welfare Mothers}

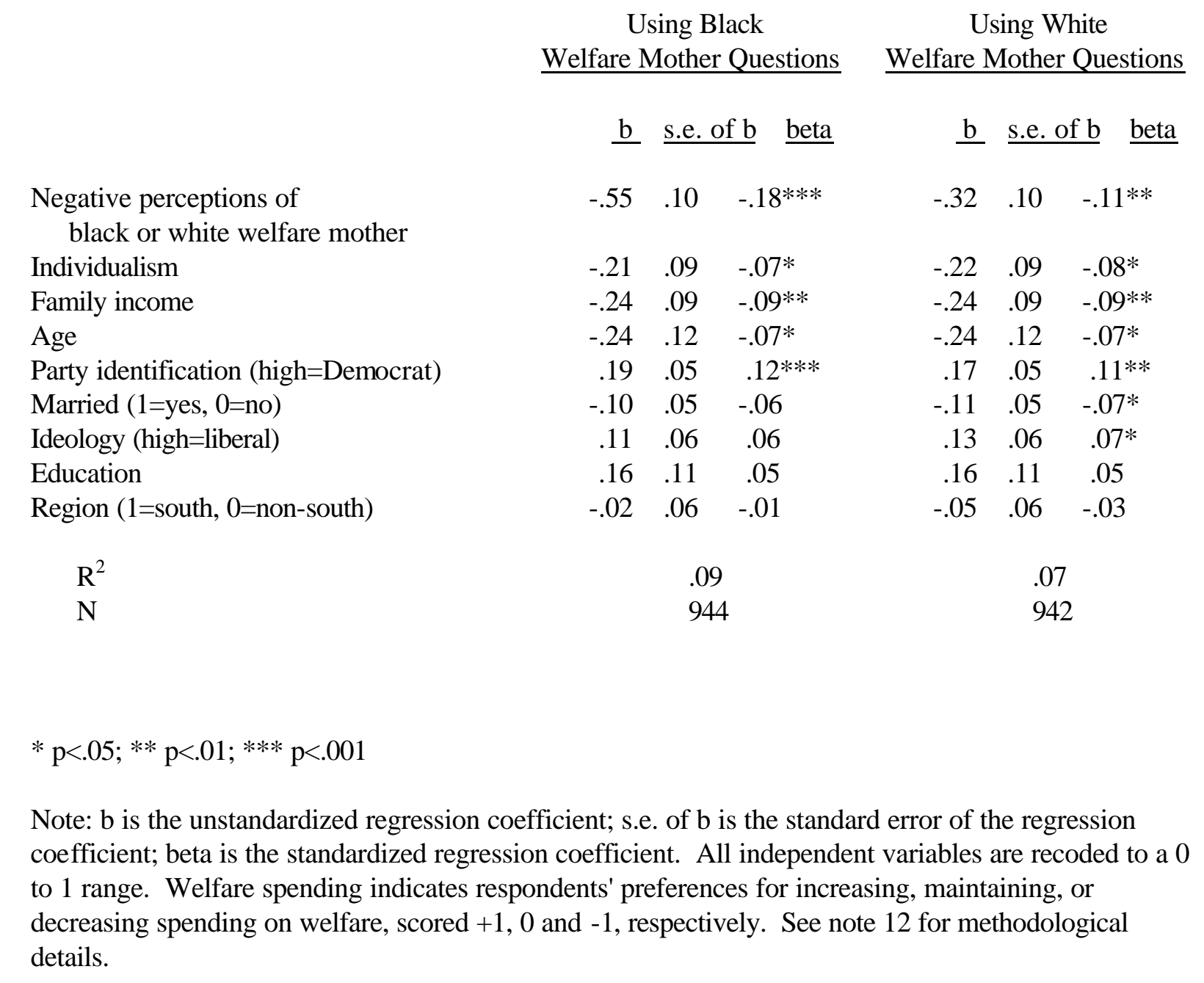


Table 7.3B

\section{Whites' Welfare Attitudes as Predicted by Perceptions of Black and White Welfare Mothers}

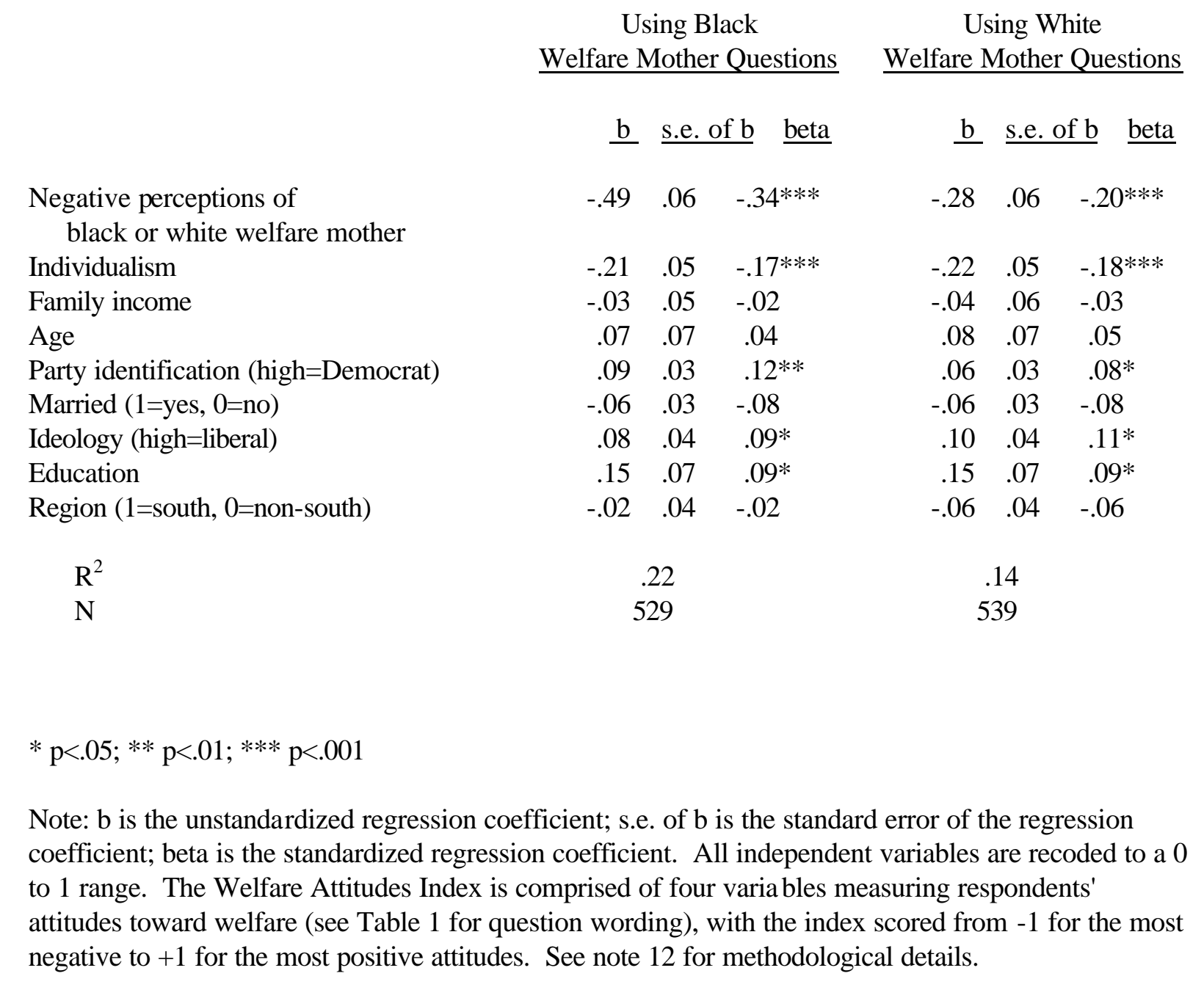


Table 7.3C

\section{Whites' Perceptions of the Poor as Lazy as Predicted by Perceptions of Black and White Welfare Mothers}

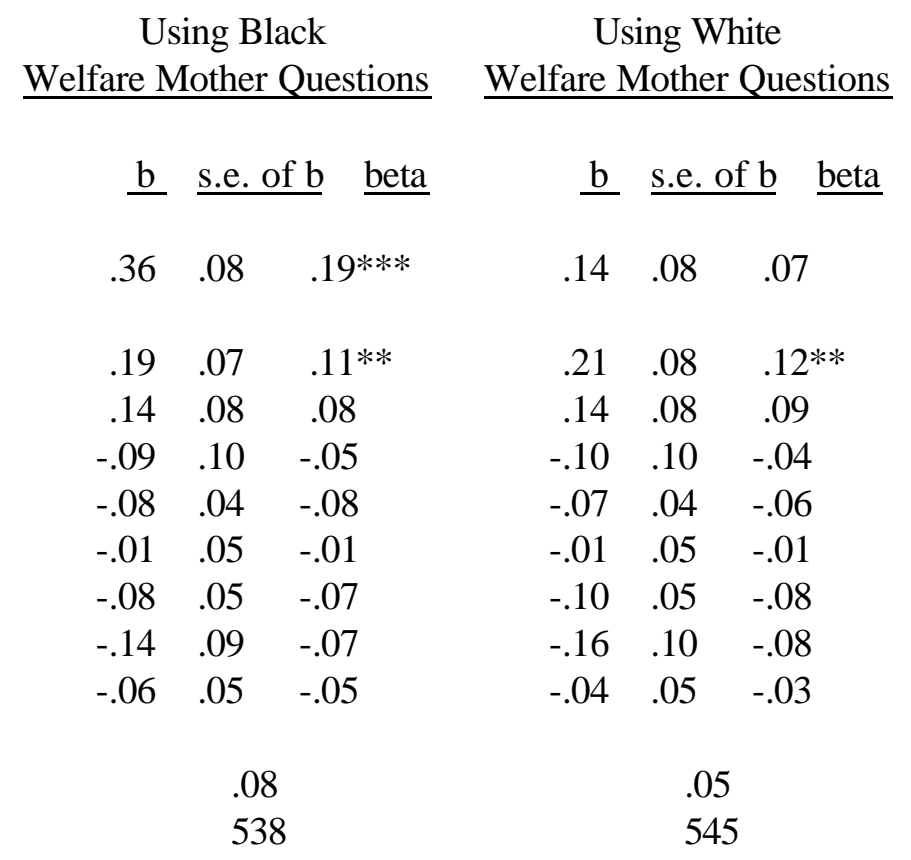

$* \mathrm{p}<.05 ; * * \mathrm{p}<.01 ; * * * \mathrm{p}<.001$

Note: $\mathrm{b}$ is the unstandardized regression coefficient; s.e. of $\mathrm{b}$ is the standard error of the regression coefficient; beta is the standardized regression coefficient. All independent variables are recoded to a 0 to 1 range. Perceptions of the poor as lazy are measured by an additive index of two variables and scored to -1 for the strongest disagreement that the poor are lazy to +1 for strongest agreement. See text for index construction, and note 12 for methodological details. 
Table 7.4

Whites' Perceptions of Black and White Welfare Mothers

Black
Welfare Mother

How likely do you think it is that she [the black or white welfare mother] will really try hard to find a job?

Very likely

Somewhat likely

Somewhat unlikely

Very unlikely
$13 \%$

40

30

17
White

$\underline{\text { Welfare Mother }}$

How likely is it that she will have more children in order to get a bigger welfare check?

Very likely

Somewhat likely

Somewhat unlikely

Very unlikely

Negative perceptions on both questions

Mixed perceptions

Positive perceptions on both questions
28

42

21

8

39

40

22
$14 \%$

40

30

17 
Figure 1. Whites' Welfare Attitudes

By Perceptions of Black and White Welfare Mothers

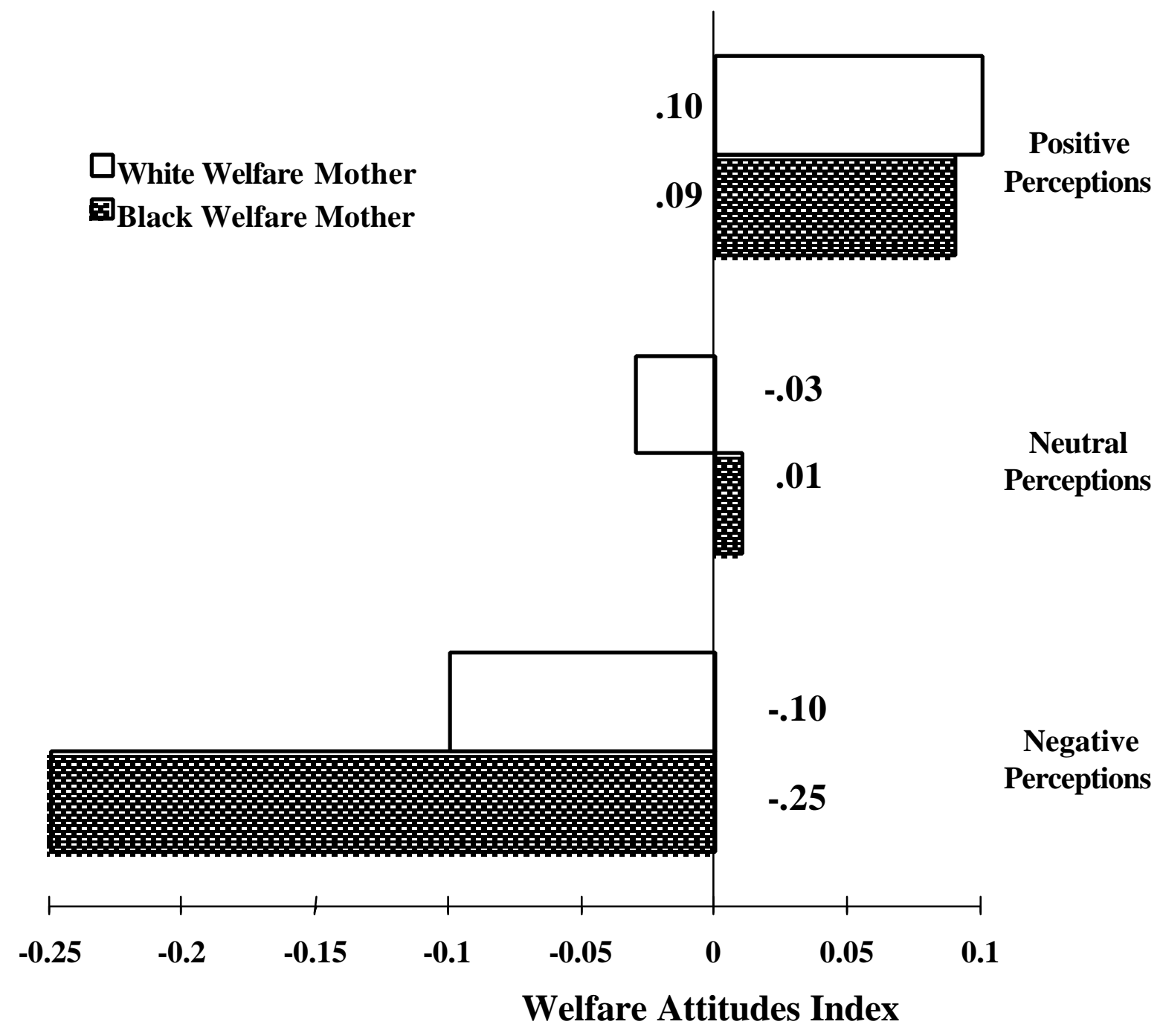

Note: The welfare attitudes index is scored from -1 for the most negative to +1 for the most positive attitudes toward welfare. See text and Table 1 for question wording, and Table 4 for the coding of perceptions of welfare mothers.

White Welfare Mother .10

Positive perceptions $\quad$ Neutral perceptions $\quad$ Negative perceptions

Black Welfare Mother .09

$.01-.25$

